\title{
Chapter 12 \\ Evaluating the Probability of Catching Fat \\ Greenlings (Hexagrammos otakii) Highly \\ Contaminated with Radiocesium off the Coast of Fukushima
}

\author{
Yuya Shigenobu, Ken Fujimoto, Daisuke Ambe, Hideki Kaeriyama, \\ Tsuneo Ono, Takami Morita, and Tomowo Watanabe
}

\begin{abstract}
On 1 August 2012, a total of 25,800 Bq/ $\mathrm{kg}$-wet of radiocesium $\left({ }^{134} \mathrm{Cs}=9,800 \mathrm{~Bq} / \mathrm{kg}\right.$-wet, ${ }^{137} \mathrm{Cs}=16,000 \mathrm{~Bq} / \mathrm{kg}$-wet $)$ was detected in the muscle tissue of two fat greenlings (Hexagrammos otakii) caught approximately $20 \mathrm{~km}$ north of the Fukushima Dai-ichi Nuclear Power Plant (FNPP). To estimate the contamination level of this fish species off the coast of Fukushima, we measured the radiocesium concentration in the muscle tissue of individual fat greenlings in 2012 and 2013. Radiocesium concentration of fat greenlings caught in southern coastal waters from the FNPP was significantly higher than that of fat greenlings collected in other waters off the coast of Fukushima. However, fat greenlings with a radiocesium concentration greater than $10,000 \mathrm{~Bq} / \mathrm{kg}$-wet were not detected, not even from highly contaminated areas. In addition, data obtained from specimens collected off the coast of Fukushima from April to December 2012 suggested that the probability of catching fat greenlings with a concentration greater than $16,000 \mathrm{~Bq} / \mathrm{kg}$-wet of ${ }^{137} \mathrm{Cs}$ was exceedingly low (less than $2.794 \times 10^{-6}$ ). In contrast, highly contaminated fat greenlings were frequently caught within the FNPP port. The geometric mean of ${ }^{137} \mathrm{Cs}$ was $55,400 \mathrm{~Bq} / \mathrm{kg}$-wet, as calculated from specimens obtained during December 2012 to May 2013. Our investigation suggests that fat greenlings with an extremely high concentration of radiocesium were contaminated within the FNPP port and then migrated offshore.
\end{abstract}

Keywords Fat greenling • Marine products • High contamination • Radiocesium - Probability

\footnotetext{
Y. Shigenobu $(\varangle) \bullet$ K. Fujimoto $\bullet$ D. Ambe $\bullet$ H. Kaeriyama $\bullet$ T. Ono $\bullet$ T. Morita National Research Institute of Fisheries Sciences, Fisheries Research Agency, 2-12-4, Fukuura, Kanazawa, Yokohama, Kanagawa 236-8648, Japan e-mail: yshig@affrc.go.jp

T. Watanabe

Tohoku National Fisheries Research Institute, Fisheries Research Agency, 3-27-5, Shinhama, Shiogama, Miyagi 985-0001, Japan e-mail:wattom@affrc.go.jp
} 


\subsection{Introduction}

Immediately after the Fukushima Dai-ichi Nuclear Power Plant (FNPP) accident in March 2011, high concentrations of radiocesium $\left({ }^{134} \mathrm{Cs}\right.$ and $\left.{ }^{137} \mathrm{Cs}\right)$ were detected in several specimens of marine products off the coast of Fukushima (Ministry of Agriculture, Forestry and Fisheries 2014). In April 2011, a concentration of $12,500 \mathrm{~Bq} / \mathrm{kg}$-wet and $14,400 \mathrm{~Bq} / \mathrm{kg}$-wet of radiocesium was detected in whole-fish specimens of Japanese sand lance (Ammodytes personatus) collected approximately $30 \mathrm{~km}$ south of the FNPP. These extremely high concentrations in coastal pelagic fish species were caused from their direct exposure to highly contaminated seawater (Bailly et al. 2012; Oikawa et al. 2013). It is known that cesium absorbed by marine organisms is excreted by their potassium ion transport system during osmoregulation (Furukawa et al. 2012; Kaneko et al. 2013). Therefore, a rapid decrease in the radiocesium concentration of seawater would reduce contamination of marine organisms, especially for pelagic fish species (Buesseler 2012; Wada et al. 2013). Temporal trends in radiocesium concentration of marine organisms off the coast of Fukushima gradually declined after the summer of 2011 (Wada et al. 2013). Marine organisms with a radiocesium concentration greater than $10,000 \mathrm{~Bq} / \mathrm{kg}$-wet were not reported until 1.5 years after April 2011. On 1 August 2012, however, a total of $25,800 \mathrm{~Bq} / \mathrm{kg}$-wet of radiocesium $\left({ }^{134} \mathrm{Cs}=9,800 \mathrm{~Bq} / \mathrm{kg}\right.$-wet; ${ }^{137} \mathrm{Cs}=16,000 \mathrm{~Bq} / \mathrm{kg}$ wet) was detected in the muscle tissue of two fat greenlings (Hexagrammos otakii) caught approximately $20 \mathrm{~km}$ north of the FNPP (Tokyo Electric Power Corporation 2012a). Although Tokyo Electric Power Corporation (2012b) had carried out an intensive investigation within the $20-\mathrm{km}$ radius from the FNPP port, such a highly contaminated fish had not been caught until that point, and the reason for this extremely high level of contamination remains unclear.

Fat greenling is a coastal demersal fish species that lives by preying on benthic organisms. A previous tagging study suggested that the migration distance of fat greenling was restricted within an area of approximately $30-\mathrm{km}$ radius (Fukushima Prefectural Fisheries Experimental Station FPFES 1974). It is assumed that in highly contaminated areas, as is the zone within and around the FNPP port, sedentary demersal fish species continuously receive radiocesium through the benthic food web more constantly than migratory demersal fish species such as Japanese flounder (see Chap. 11) and Pacific cod (see Chap. 10). In this section, we measured radiocesium concentration in the muscle tissue of individual fat greenlings caught off the coast of Fukushima to estimate the contamination level in this fish species. In addition, we attempted to calculate the probability that ${ }^{137} \mathrm{Cs}$ concentration exceeds $16,000 \mathrm{~Bq} / \mathrm{kg}$-wet in fat greenlings collected off the coast of Fukushima from April 2012 to March 2013, using our original data in combination with datasets published by the Ministry of Agriculture, Forestry and Fisheries (MAFF) and TEPCO (2014). 


\subsection{Radiocesium Contamination of Fat Greenlings off the Coast of Fukushima}

From May 2012 to March 2013, we collected 236 fat greenlings in northern (approximately $50 \mathrm{~km}$ north of the FNPP) and southern (approximately $40 \mathrm{~km}$ south of the FNPP) waters (Fig. 12.1). Radiocesium concentration was measured as described by Shigenobu et al. (2014). Fat greenlings caught from the northern waters had a relatively lower radiocesium concentration than those collected from the southern waters (Table. 12.1). In the southern waters, the level of contamination was significantly higher $(p<0.001)$ in coastal waters, at depth less than $30 \mathrm{~m}$ (geometric mean, $128 \mathrm{~Bq} / \mathrm{kg}$-wet) than in offshore waters, at depth greater than $50 \mathrm{~m}$ (geometric mean, $28.4 \mathrm{~Bq} / \mathrm{kg}$-wet). The highest radiocesium concentration detected was $1,070 \mathrm{~Bq} / \mathrm{kg}$-wet in a fat greenling collected from the southern coastal waters on 20 May 2012. In this study, none of the fish specimens had a radiocesium concentration higher than $10,000 \mathrm{~Bq} / \mathrm{kg}$-wet weight.

Figure 12.2 shows the time-series trend of radiocesium concentration of fat greenlings caught within the FNPP port and off the coast of Fukushima from May

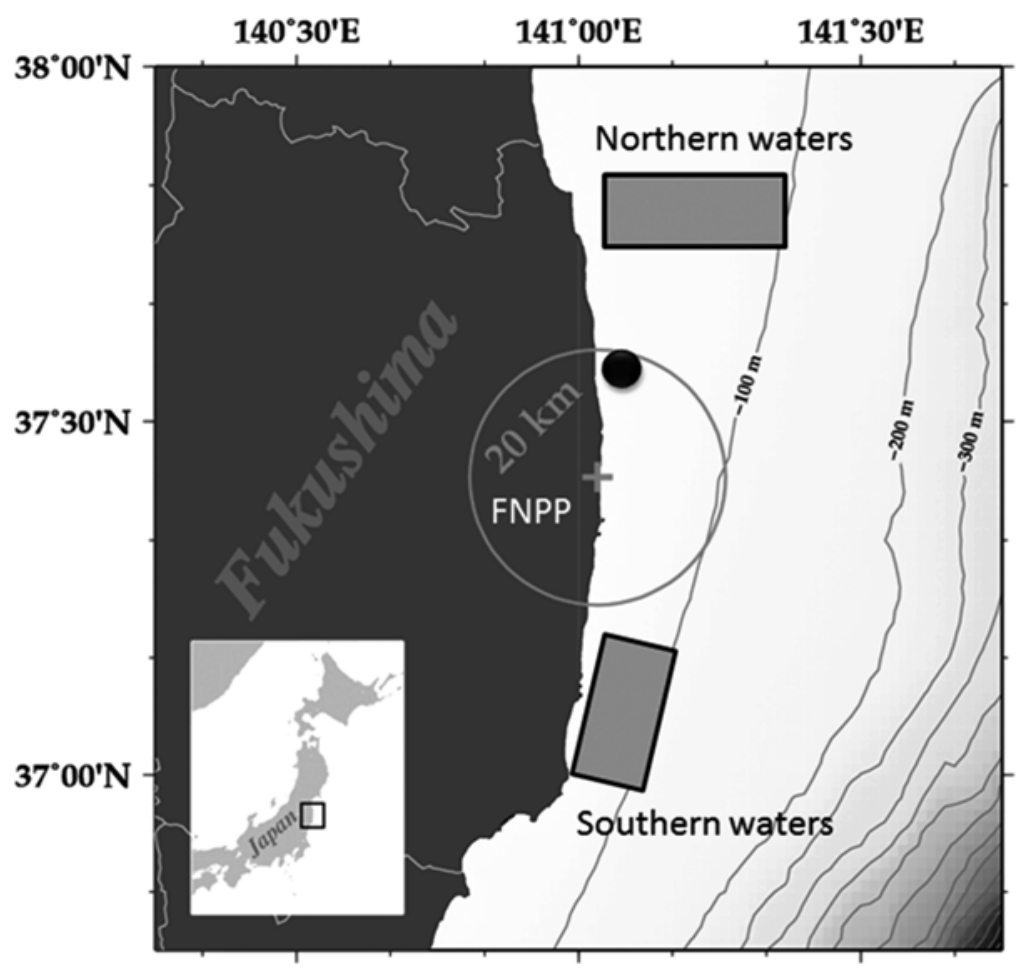

Fig. 12.1 Fat greenlings were collected from several sampling locations. The gray circle indicates a sampling area of approximately 20-km radius around the Fukushima Dai-ichi Nuclear Power Plant (FNPP), and the black spot indicates the sampling point, where fat greenlings with a $25,800 \mathrm{~Bq} / \mathrm{kg}$-wet radiocesium concentration were caught on 1 August 2012 
Table 12.1 Radiocesium concentrations in individual fat greenlings off the coast of Fukushima

\begin{tabular}{|c|c|c|c|c|}
\hline \multirow[b]{3}{*}{ Sampling area } & \multirow[b]{3}{*}{$\begin{array}{l}\text { Number of } \\
\text { individuals }\end{array}$} & \multicolumn{3}{|c|}{$\begin{array}{l}{ }^{134} \mathrm{Cs}+{ }^{137} \mathrm{Cs} \text { concentration } \\
(\mathrm{Bq} / \mathrm{kg} \text {-wet })\end{array}$} \\
\hline & & \multicolumn{3}{|l|}{ Range } \\
\hline & & Min. & Max. & $\begin{array}{l}\text { Geometric } \\
\text { mean }^{\mathrm{a}}\end{array}$ \\
\hline $\begin{array}{l}\text { Northern coastal waters (at depth less } \\
\text { than } 30 \mathrm{~m} \text { ) }\end{array}$ & 30 & 4.46 & 39.2 & 13.1 \\
\hline $\begin{array}{l}\text { Northern offshore waters (at depth } \\
\text { more than } 50 \mathrm{~m} \text { ) }\end{array}$ & 54 & $\begin{array}{l}\text { n.d. } \\
(<4.24)\end{array}$ & 193 & 21.9 \\
\hline $\begin{array}{l}\text { Southern coastal waters (at depth less } \\
\text { than } 30 \mathrm{~m} \text { ) }\end{array}$ & 68 & $\begin{array}{l}\text { n.d. } \\
(<5.31)\end{array}$ & 1,070 & 128 \\
\hline $\begin{array}{l}\text { Southern offshore waters (at depth } \\
\text { more than } 50 \mathrm{~m} \text { ) }\end{array}$ & 84 & $\begin{array}{l}\text { n.d. } \\
(<3.28)\end{array}$ & 987 & 28.4 \\
\hline
\end{tabular}

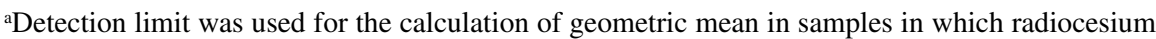
was not detected (n.d.)

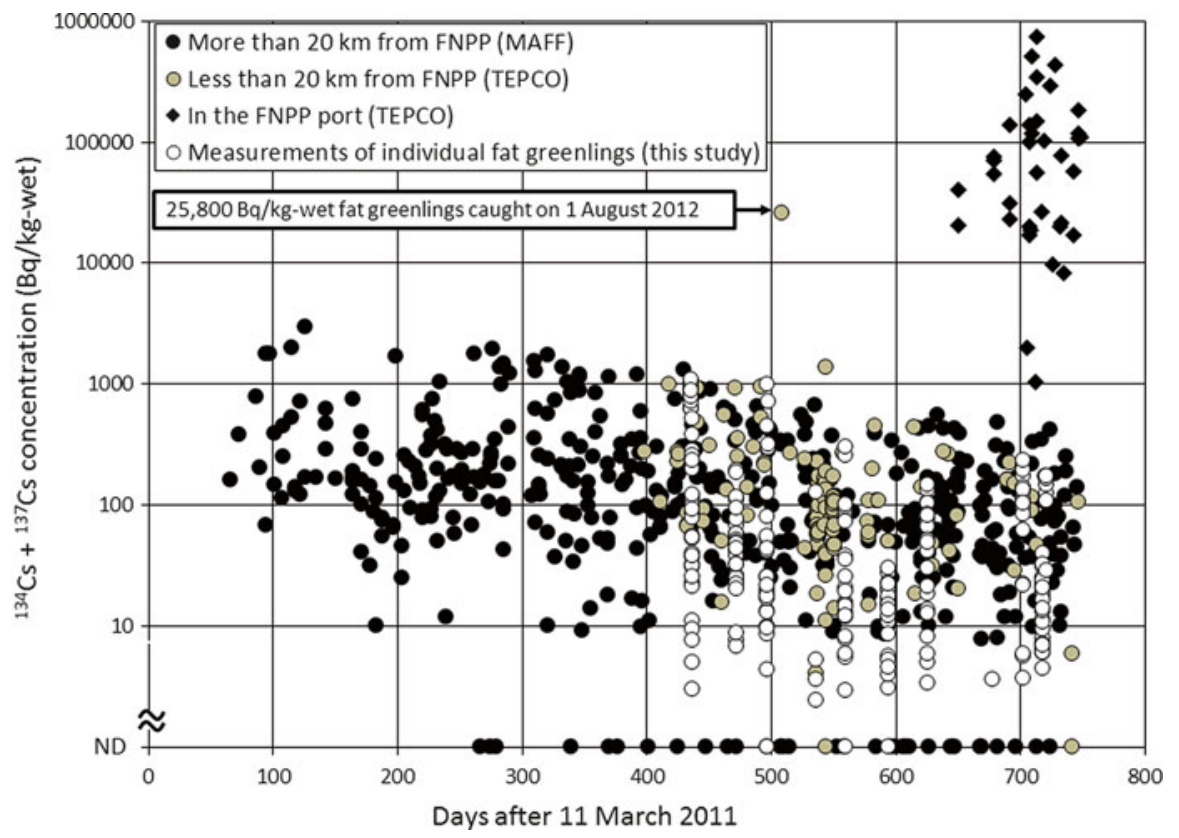

Fig. 12.2 Temporal trend of radiocesium concentration $\left({ }^{134} \mathrm{Cs}+{ }^{137} \mathrm{Cs}\right)$ in fat greenlings caught within and outside an area of approximately $20-\mathrm{km}$ radius around the Fukushima Dai-ichi Nuclear Power Plant (FNPP). Tokyo Electric Power Corporation (2012b) has been monitoring marine organisms within an area of 20-km radius around FNPP since April 2012 
2011 to May 2013, using our original data and datasets published from MAFF and TEPCO. Radiocesium concentration of fat greenlings caught off the coast of Fukushima gradually declined over time. Except for the datasets of fat greenlings collected within the FNPP port, radiocesium concentration exceeded the Japanese threshold (100 Bq/kg-wet) in $76.3 \%$ and $41.2 \%$ of specimens caught off the coast of Fukushima in 2011 and 2012, respectively. In particular, geometric means were $209 \mathrm{~Bq} / \mathrm{kg}$-wet in specimens collected from April to December 2011 and $77.2 \mathrm{~Bq} /$ $\mathrm{kg}$-wet in those collected from April to December 2012.

Previous studies have reported that radiocesium concentration in marine organisms (Wada et al. 2013) and sediments (Ambe et al. 2014) within the southern coastal area of FNPP was comparatively higher than those in other areas. However, according to our data and published datasets from MAFF and TEPCO, fat greenlings with a radiocesium concentration greater than $10,000 \mathrm{~Bq} / \mathrm{kg}$-wet were not identified, not even in specimens collected from highly contaminated areas. This circumstantial evidence suggests a low probability of catching extremely highly contaminated fat greenling off the coast of Fukushima. Our field investigation and laboratory-rearing experiments of a benthic polychaete in highly contaminated sediment suggests that radiocesium intake from contaminated sediments is limited for benthic organisms and demersal fish species (see Chap. 7). Progressive simulation analysis of the contamination mechanism in fat greenling off the coast of Fukushima is presented in Chap. 13.

\subsection{Site of Contamination of the Highly Contaminated Fat Greenling}

Data of ${ }^{137} \mathrm{Cs}$ concentration in fat greenling specimens collected off the coast of Fukushima from April to December 2012 were log-transformed. A normal distribution curve of log-transformed values was used to calculate the probability of catching fat greenlings with $\mathrm{a}^{137} \mathrm{Cs}$ concentration greater than $16,000 \mathrm{~Bq} / \mathrm{kg}$-wet (log-transformed value of 4.204) as shown in Fig. 12.3. Values below the detection limit of ${ }^{137} \mathrm{Cs}$ were excluded from this analysis to obtain a more conservative estimate. Normality of the log-transformed values from the combined datasets was confirmed. Arithmetic mean \pm standard deviation of $\log$-transformed ${ }^{137} \mathrm{Cs}$ concentration was $1.676 \pm 0.5567$. The calculated probability of catching fat greenlings with a concentration greater than $16,000 \mathrm{~Bq} / \mathrm{kg}$-wet of ${ }^{137} \mathrm{Cs}$ was below $2.794 \times 10^{-6}$. This very low value strongly suggests that fat greenlings off the coast of Fukushima from April to December 2012 did not include any highly contaminated individuals.

In contrast, the level of radiocesium contamination in fat greenlings caught in the FNPP port from December 2012 to May 2013 was extremely high. The geometric mean was $55,400 \mathrm{~Bq} / \mathrm{kg}$-wet and ranged from 1,030 to 740,000 Bq/kg-wet. Kanda (2013) reported that the average values of ${ }^{137} \mathrm{Cs}$ concentration in seawater samples collected from the intake canal area of Units 1-4 of the FNPP from June to August 2011 ranged between 305 and 1,650 Bq/l. Concentration ratio (CR) of the 25,800 Bq/ 


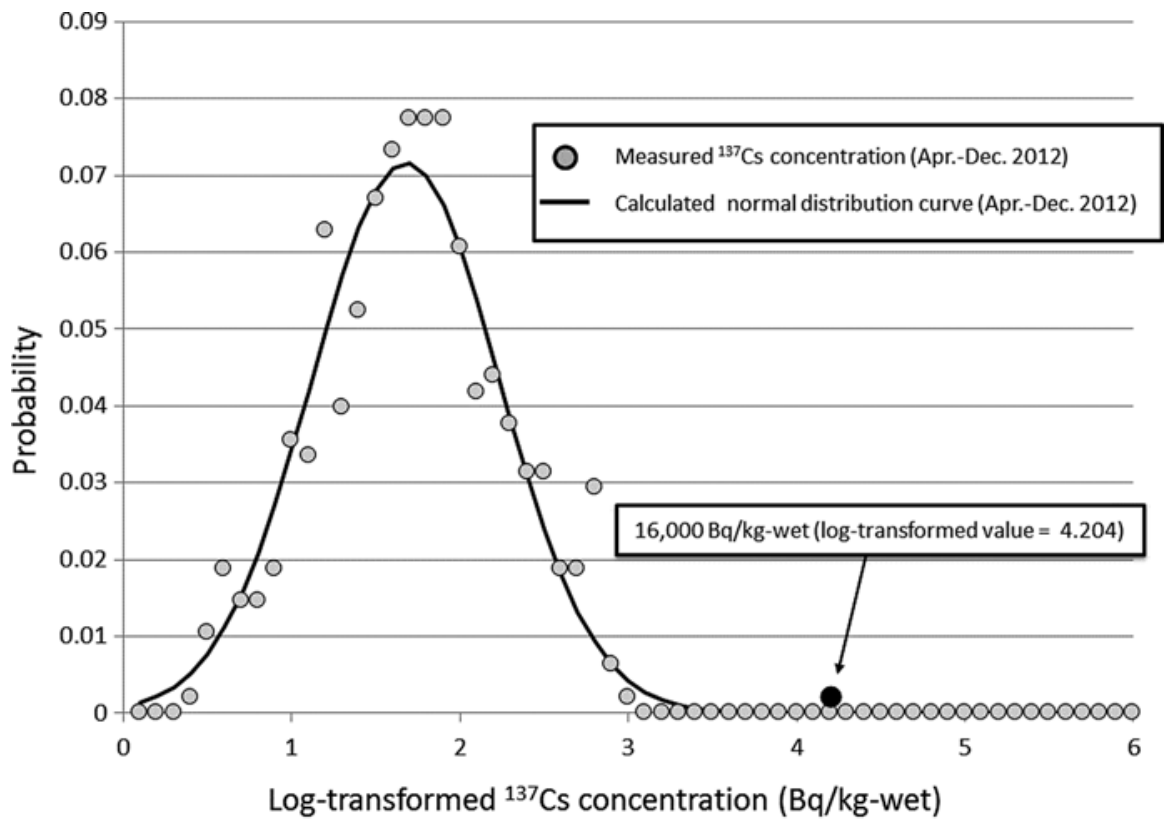

Fig. 12.3 Probability of catching contaminated fat greenlings off the coast of Fukushima. The normal distribution curve was constructed using log-transformed ${ }^{137} \mathrm{Cs}$ concentration in specimens collected from April to December 2012. Black spot indicates the $16,000 \mathrm{~Bq} / \mathrm{kg}$-wet ${ }^{137} \mathrm{Cs}$ concentration. The probability of catching fat greenlings with a ${ }^{137} \mathrm{Cs}$ concentration greater than $16,000 \mathrm{~Bq} /$ kg-wet was less than approximately $2.794 \times 10^{-6}$

kg-wet $\left({ }^{137} \mathrm{Cs}\right.$ of $16,000 \mathrm{~Bq} / \mathrm{kg}$-wet) fish specimens to the seawater from the intake canal area of Units 1-4 was between 9.70 and 52.5 for the period of June to August 2011. These results were consistent with previous findings that $\mathrm{CR}$ of ${ }^{137} \mathrm{Cs}$ between demersal fish species and seawater around Japan ranged from 15 to 54 (Tagami and Uchida 2013). The results also indicated that the contamination level within the FNPP was much higher immediately after the FNPP accident. Accordingly, for a period of several months after the FNPP accident, the radiocesium contamination level of fat greenlings within the FNPP port was never less than 25,800 Bq/kg-wet. Although the site where the extremely contaminated fat greenlings were caught was 20-km away from FNPP, this distance is within the possible migration distance for this species (FPFES 1974). Therefore, it is assumed that the extremely contaminated fat greenlings had been exposed to highly contaminated seawater over a certain period of time after the accident within or near the FNPP port before they migrated offshore.

Acknowledgments This section is based on the article entitled "Radiocesium contamination of greenlings (Hexagrammos otakii) off the coast of Fukushima" published in the open access journal of Scientific Reports (doi: 10.1038/srep06851). The authors wish to thank all the fishery workers in 
Fukushima Prefecture who collected the greenlings for this study. We also thank all the members of our research group for their assistance with specimen preparation. This study was supported by the Fisheries Agency, the Ministry of Agriculture, and the Forestry and Fisheries of Japan.

Open Access This chapter is distributed under the terms of the Creative Commons Attribution Noncommercial License, which permits any noncommercial use, distribution, and reproduction in any medium, provided the original author(s) and source are credited.

\section{References}

Ambe D, Kaeriyama H, Shigenobu Y, Fujimoto K, Ono T, Sawada H, Saito H, Miki S, Setou T, Morita T, Watanabe T (2014) Five-minute resolved spatial distribution of radiocesium in sea sediment derived from the Fukushima Dai-ichi Nuclear Power Plant. J Environ Radioact 138:264-275

Bailly du Bois P, Laguionie P, Korsakissok I, Didier D, Fiévet B (2012) Estimation of marine source-term following Fukushima Daiichi accident. J Environ Radioact 114:2-9

Buesseler KO (2012) Fishing for answers off Fukushima. Science 338:480-482

Fukushima Prefectural Fisheries Experimental Station (FPFES) (1974) Research report of resource ecology and fisheries for selected three rockfish species (Hexagrammos otakii, Sebastes inermis and Sebastes vulpes) in North Pacific waters of Japan (in Japanese)

Furukawa F, Watanabe S, Kaneko T (2012) Excretion of cesium and rubidium via the branchial potassium-transporting pathway in Mozambique tilapia. Fish Sci 78:597-602

Kanda J (2013) Continuing ${ }^{137}$ Cs release to the sea from the Fukushima Daiichi Nuclear Power Plant through 2012. Biogeosciences 10:6107-6113

Kaneko T, Furukawa F, Watanabe S (2013) Excretion of cesium through potassium transport pathway in the gills of a marine teleost. In: Nakanishi TM, Tanoi K (eds) Agricultural implications of the Fukushima nuclear accident. Springer Japan, Tokyo, pp 105-118

Ministry of Agriculture, Forestry and Fisheries (2014) http://www.jfa.maff.go.jp/e/inspectio n/ index.html. Accessed 12 June 2014

Oikawa S, Takata H, Watabe T, Misonoo J, Kusakabe M (2013) Distribution of the Fukushimaderived radionuclides in seawater in the Pacific off the coast of Miyagi, Fukushima, and Ibaraki Prefectures, Japan. Biogeosciences 10:5031-5047

Shigenobu Y, Fujimoto K, Ambe D, Kaeriyama H, Ono T, Morinaga K, Nakata K, Morita T, Watanabe T (2014) Radiocesium contamination of greenlings (Hexagrammos otakii) off the coast of Fukushima. Sci Rep 4. doi:10.1038/srep06851

Tagami K, Uchida S (2013) Marine and freshwater concentration ratios $\left(\mathrm{CR}_{\text {wo-water }}\right)$ : review of Japanese data. J Environ Radioact 126:420-436

Tokyo Electric Power Corporation (2012a) Result of radioactive nuclide analysis (fat greenling). http://photo.tepco.co.jp/date/2012/201208-j/120821-01j.html. Accessed 12 June 2014 (in Japanese)

Tokyo Electric Power Corporation (2012b) Handouts at press conference I Archives. http://www. tepco.co.jp/en/nu/fukushima-np/handouts/indexold-e.html. Accessed 12 June 2014

Wada T, Nemoto Y, Shimamura S, Fujita T, Mizuno T, Sohtome T, Kamiyama K, Morita T, Igarashi S (2013) Effects of the nuclear disaster on marine products in Fukushima. J Environ Radioact 124:246-254 